\title{
Macrozamia johnsonii, a new species of Macrozamia section Macrozamia (Zamiaceae) from northern New South Wales
}

\author{
D.L. Jones and K.D. Hill
}

\begin{abstract}
Jones, D.L. ${ }^{1}$, and Hill, K.D. ${ }^{2}{ }^{1}$ Australian National Botanic Gardens, GPO Box 1777, Canberra, ACT, Australia 2601; ${ }^{2}$ Royal Botanic Gardens, Sydney, NSW, Australia 2000) 1992. Macrozamia johnsonii, a new species of Macrozamia section Macrozamia (Zamiaceae) from northern New South Wales. Telopea 5(1): 31-34. Macrozamia johnsonii, a previously undescribed species confused with M. moorei, is described and figured below.
\end{abstract}

\section{Macrozamia johnsonii $D$. Jones \& $K$. Hill, sp. nov.}

M. moorei F. Muell. affinis sed habitu breviore, frondibus viridibus, foliolis amphistomaticis et plantula dissimili (petiolo tereti, rhachidi recta vix tortili ad apicem non curvata, et pinnis late patentibus falcatis nitenti-viridibus tenuibus, hypostomaticis, cum basi callosa alba) differt.

TYPe: New SOUth WALES: c. $12 \mathrm{~km}$ east of Dalmorton on slopes above the Nymboida River, D. Jones 6748 and C. H. Broers, 18 October 1990 (holo CBG; iso BRI, CBG, NSW)

Trunk broadly cylindrical $0.3-1.5 \mathrm{~m}$ tall, to $80 \mathrm{~cm}$ diameter. Fronds very numerous, bright green, to 120 in the crown, at first erect, later spreading obliquely, then drooping, 1.5-3 m long on mature plants, flat in cross-section, straight to arching in profile; spine-free petiole (excluding the woolly, swollen base) $2-8 \mathrm{~cm}$ long; rhachis not twisted or with a very gentle half spiral, more or less flattened, usually $25-28 \mathrm{~mm}$ broad at the lowest pinnae, shallowly convex above (sometimes with 2 or 3 broad furrows in the proximal region) with 2 narrow lateral grooves decurrent from the bases of the pinnae, convex beneath. Pinnae 150-250, widely spreading, inserted on the rhachis at about 40 degrees, moderately crowded $(0.5-2 \mathrm{~cm}$ apart), moderately rigid, pungent-tipped, entire, straight, linear, 40 or more of the lower ones progressively reduced, rigid and spine-like; median leaflets linear, 20-40 cm x 5-11 mm, with 7-12 scarcely raised nerves beneath, amphistomatic, gradually tapered to the pungent apex, contracted to the whitish, anteriorly callous, more or less rugose base. Cones pedunculate, the females $1-6$, the males $10-50$ per plant, axillary amongst the lower fronds, the base of the peduncle surrounded by several, brownish, spine-like, angular, subulate, ligulate cataphylls 8-15 cm long; reduced, decurrent cataphylls present also on the peduncle. Male cones cylindrical, semi-erect to spreading, straight or more usually curved, $25-40 \mathrm{~cm}$ long, $8-10 \mathrm{~cm}$ diameter; sporophylls cuneate, $1.8-3 \mathrm{~cm} \mathrm{x}$ $1.2-1.8 \mathrm{~cm}$, with an apical, erect, spine-like appendage $0.2-2 \mathrm{~cm}$ long, the longest ones on the distal sporophylls; peduncle $10-12.5 \mathrm{~cm}$ long, $2-3 \mathrm{~cm}$ diameter. Female cones cylindrical to barrel-shaped, green with pink areas on the sporophylls, $50-80$ $\mathrm{cm}$ long, 10-20 cm diameter, usually spreading, drooping with age; sporophylls $5-7$ $\mathrm{cm}$ long, broadly cuneate, expanded towards the apex where glaucous ( $3-6 \mathrm{~cm}$ across), with an apical, erect, spine-like appendage 3-7 cm long, the longest ones on the distal sporophylls; peduncle 15-22 cm long, 3-4 cm diameter. Seeds $4-6 \mathrm{~cm}$ long, $2.5-3 \mathrm{~cm}$ thick, oblong, sarcotesta bright red. 


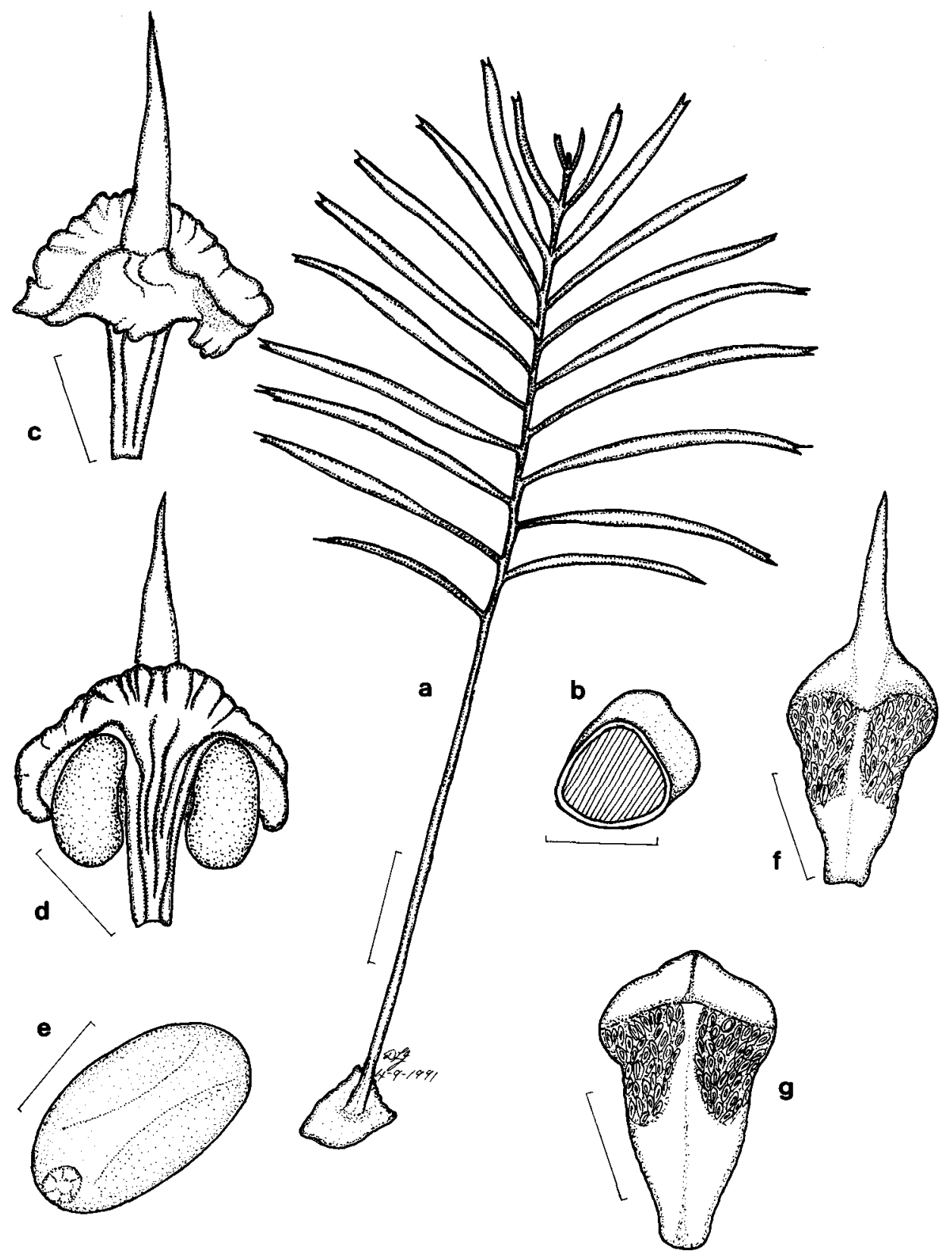

Figure 1. Macrozamia johnsonii. a, seedling leaf; $\mathbf{b}$, cross-section through rhachis; $\mathbf{c}$, female sporophyll from above; $\mathbf{d}$, female sporophyll from below; $\mathbf{e}$, seed; $\mathbf{f}$, male sporophyll (from below) from apical portion of cone; $\mathbf{g}$, male sporophyll (from below) from basal portion of cone (all from Jones 6748). Scale bar: $\mathrm{a}, \mathrm{c}, \mathrm{d}, \mathrm{e}=2 \mathrm{~cm} ; \mathrm{f}, \mathrm{g}=1 \mathrm{~cm} ; \mathrm{b}=2 \mathrm{~mm}$. 
Distribution and habitat: Occurring on the North Coast Region of New South Wales where it grows on sheltered ridges and steep southerly and easterly slopes in wet and dry sclerophyll forest. The soils are skeletal clay loams with shale fragments over shale.

Selected sPecimens: New South Wales: North Coast: 3 miles $(\mathrm{c} .5 \mathrm{~km})$ E of Dalmorton, Morris, Jan 1960 (NSW 49023 - juvenile, NSW 49024 - adult); Marara Creek, Dalmorton, Floyd AGF 1215 (adult), AGF 1216 (juvenile), 21 Feb 1979 (NSW); Tower Hill Creek, Dalmorton, Constable, 29 Oct 1952 (NSW); 3 miles (c. $5 \mathrm{~km}$ ) E of Dalmorton, Johnson \& Constable, 7 June 1957 (NSW 43070 juvenile, previously determined as M. lucida, NSW 42180 - adult).

Notes: $M$. johnsonii is closely related to $M$. moorei and has been included with that taxon (Johnson 1961). $M$. johnsonii never develops the tall, massive trunks of $M$. moorei and has green rather than grey-green fronds. In addition, the seedlings of each are quite distinct. Those of $M$. johnsonii have a nearly rounded petiole, a straight, hardly twisted rhachis not recurved at the tip and widely spreading falcate pinnae that are shiny green, hypostomatic, thin-textured, with a prominent white callous base obvious from an early age. Development of shiny, hypostomatic pinnae continues on juvenile plants for several years, then an abrupt change to the adult form occurs, in which the pinnae are amphistomatic. Seedlings of $M$. moorei have a petiole flat on the adaxial surface, a prominently twisted rhachis recurved at the tip and erect, straight pinnae which are dull, amphistomatic, dark blue-green, with a callous base which is prominent only on later fronds. Seedling pinnae resemble adult pinnae from a very early stage and are always amphistomatic. $M$. johnsonii and $M$. moorei are separated geographically by a distance of about $800 \mathrm{~km}$. M. johnsonii is locally common in the Dalmorton area and grows in large colonies that are regenerating freely.

Macrozamia lucida has been reported from the Dalmorton area of New South Wales on the basis of sterile specimens (Johnson 1961). Later extensive searches of the area by various collectors have failed to locate fertile material (Johnson pers. comm.; Floyd, in litt. herb. NSW). Collections from the same plant (Floyd AGF 1215, AGF 1216) show that leaves of the juvenile stage of $M$. johnsonii develop a long spine-free petiole and glossy hypostomatic pinnae with more or less prominent veins on the undersurface. In these respects, they resemble adult leaves of $M$. lucida, although the latter have more prominent white basal callous regions on the pinnae. The two Floyd collections include one leaf with the long spine-free petiole and hypostomatic pinnae, and one with spinescent lower pinnae and amphistomatic pinnae, both from the same plant. All records of $M$. lucida from New South Wales are now regarded as resulting from confusion with juvenile stages of $M$. johnsonii.

COnSERvation Status: 2R (Briggs and Leigh 1988). M. johnsonii occurs exclusively in state forests and is not included in any reserve. Although not specifically protected, large populations occur in areas unlikely to be under immediate threat, and the species is not considered to be threatened in the short term.

ETYMology: The name honours Lawrence A. S. Johnson, in recognition of his pioneering studies in the Cycadaceae and Zamiaceae. 


\section{Acknowledgements}

The authors wish to thank Alex George for the Latin diagnosis, Corinna Broers for assistance in the field, Joy Everett for commenting on the manuscript and Paul Kennedy, Stan Walkley and Rick Stokes for discussions about this species. Discussions with L. A. S. Johnson have helped resolve the confusion surrounding the occurrence of $M$. lucida in New South Wales.

\section{References}

Briggs, J. D. \& Leigh, J. H. (1988) Rare or threatened Australian plants. Australian National Parks and Wildlife Service: Special Publication 14.

Johnson, L. A. S. (1961) Zamiaceae. Contr. New South Wales Natl. Herb., Flora Series 1: 21-41.

Manuscript received 23 September 1991

Manuscript accepted 13 March 1992 